\title{
Geotechnical studies of the Lam Ta Khong pumped storage project, Thailand
}

\author{
Ganesh P. Dhakal', Kazumoto Onodera ${ }^{2}$, and Tetsuro Yoneda' \\ 'Graduate School of Engineering, Hokkaido University, Sapporo, 060-8628, Japan \\ ${ }^{2}$ Electric Power Development Co., Ltd., 6-chome, 15-1 Ginza, Chuo-ku, Tokyo, 104-8165, Japan
}

\begin{abstract}
The Lam Ta Khong Project in Nakhornratchasima is the biggest pumped storage hydropower project of Thailand. The project is capable of producing $1,000 \mathrm{MW}$ of electricity at the peak hour of demand. It consists of an upper pond transitory reservoir, twin inclined penstocks, a powerhouse, twin surge chambers, and twin tailrace tunnels. The powerhouse is underground with the dimensions of $175 \times 25 \times 50 \mathrm{~m}^{3}$, and houses 4 (each of $250 \mathrm{MW}$ capacity) Francis type reversible pump turbines.
\end{abstract}

The rock mass classification system of the Electric Power Development Co. Ltd. (EPDC), Japan, was used in the project area in order to select an appropriate support system for the tunnel. The majority of rocks in the project area are sandstone and siltstone. The sandstone is interbedded with claystone at shallow depths. The sandstone at greater depths is finegrained and contains two sets of joint nearly perpendicular to each other and almost vertical. These joints were responsible for frequent block falls during the excavation. Especially, the joint surfaces with slickensides contributed to frequent block falls. The near-surface highly weathered rocks required stronger support for the excavated part than the less weathered ones at greater depths. The deformation of rock mass due to excavation in the powerhouse was monitored by nine multiple borehole extensometers with one to four measuring heads (points). The monitoring results showed safe conditions in the powerhouse.

\section{INTRODUCTION}

The number of underground constructions such as tunnels, powerhouses, and mines is going to increase significantly in Thailand in the near future. Such constructions are preferred since there is less space available on the surface and they are safer. The Electricity Generating Authority of Thailand (EGAT) began a preliminary study in 1985 for the Lam Ta Khong pumped storage scheme to fulfil the peak power demand of Thailand. The project area is located in the Korat Plateau, about $190 \mathrm{~km}$ northeast of Bangkok in the Nakhornratchasima Province (Fig. 1). The project is planning to take advantage of the existing Lam $\mathrm{Ta}$ Khong Reservoir (which was constructed by the Royal Irrigation Department as a water supply and irrigation project in 1974), and the high plateau that rises east of the reservoir site and permits the development of a maximum head of $400 \mathrm{~m}$. It is the first big pumped storage hydropower project in Thailand, which is going to produce $1,000 \mathrm{MW}$ of electricity at the peak hour of demand from the middle of 2001.

The project consists of an upper pond transitory reservoir, twin inclined penstocks, an underground powerhouse, twin surge chambers, and twin tailrace tunnels (each of $1.4 \mathrm{~km}$ length). The underground powerhouse, the first of its kind in Thailand with the dimension of $175 \times 25 \times 50 \mathrm{~m}^{3}$, houses 4 (each of $250 \mathrm{MW}$ capacity) Francis-type reversible pump turbines.

\section{GEOLOGY OF THE AREA}

The area is located in the middle of the Indo-China plate with no record of any destructive earthquakes since $1500 \mathrm{AD}$ (EGAT 1995). The Korat Group of sedimentary rocks of Jurassic age are distributed in the project area, which are divided into the Phu Kradung and Phra Wiham Formations in an ascending order. The Phu Kradung Formation consists mostly of siltstone, but also contains some intercalated sandstone and conglomerate. The Phra Wiham Formation conformably overlies the Phu Kradung Formation in the project area, and contains an intercalation of coarse-grained sandstone, fine-grained sandstone, siltstone, and claystone. The coarse- and fine-grained sandstones are massive and completely consolidated whereas the siltstone is less consolidated, and the claystone is slightly consolidated. The beds are gently dipping and moderately jointed.

In the project area, the top part of the rock sequence comprises yellow-brown, medium- to coarse-grained, weathered sandstone with an intercalation of red-purple claystone, which is followed by reddish purple siltstone. Ash-grey sandstone is another sequence underlain by the siltstone. It is hard, fine-grained, and fresh. The claystone changes into mud within several minutes under the wet conditions. The siltstone and sandstone that constitute the foundations for the structures are thinly bedded and moderately to highly jointed. They often contain inclusions 


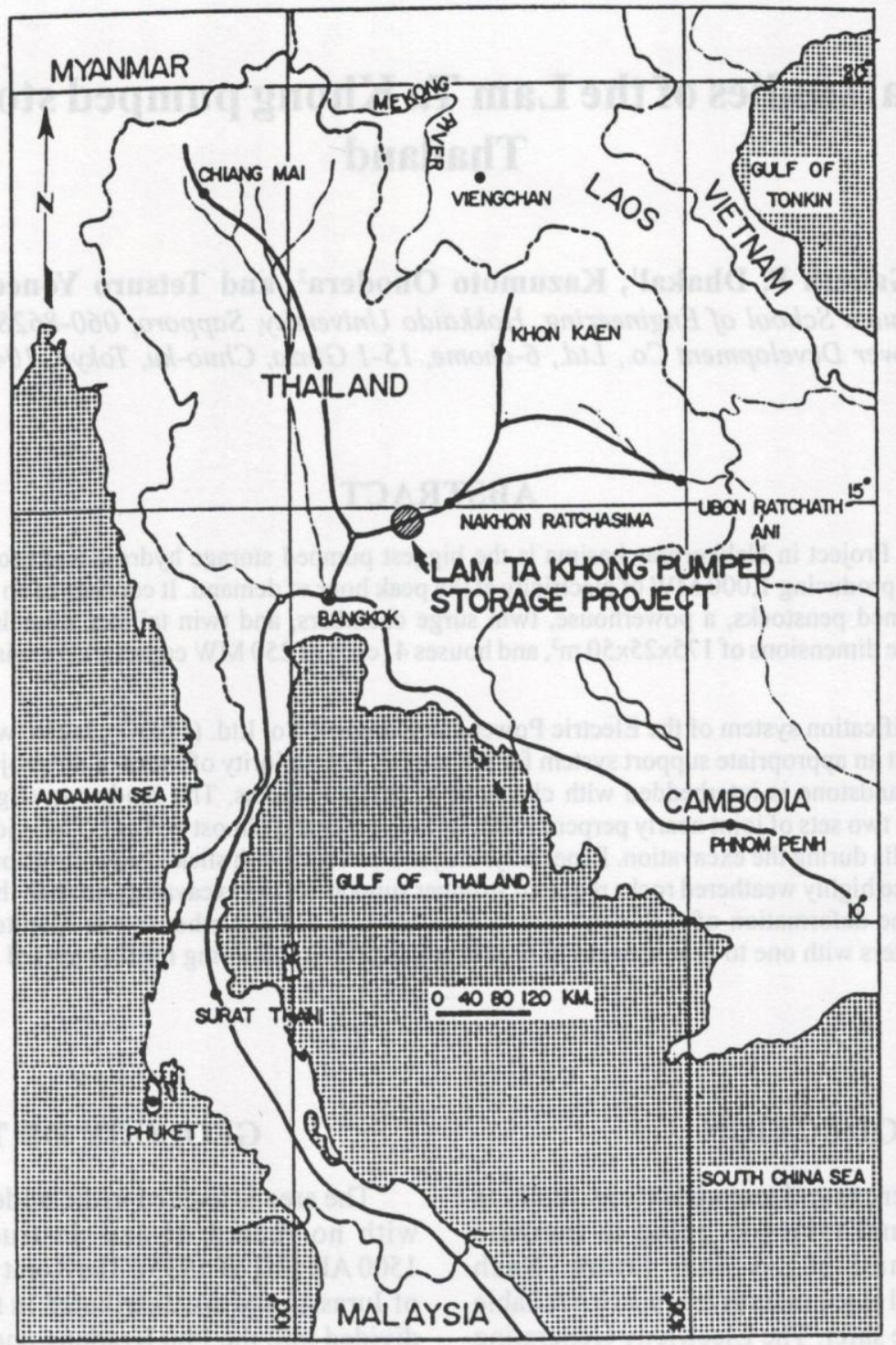

Fig. 1: Location map of the Lam Ta Khong Project, Nakhornratchasima, Thailand

of soft claystone and unconsolidated conglomerate. The geological cross-section and primary underground features of the project area are shown in Fig. 2.

\section{ROCK MASS CLASSIFICATION USED TO DECIDE THE SUPPORT SYSTEM}

The rock mass classification system of the Electric Power Development Co. Ltd. (EPDC 1992), Japan, was used to assess the rock strength and decide the tunnel support. For this purpose, rock mass rating (RMR) value was calculated by using the geomechanics classification of Bieniawski (1989). A brief outline of the EPDC (1996) is presented in Fig. 3.

The rocks of the project area were divided into SS-1, SS-2, SS-3, ST-1, ST-2, and ST-3 classes on the basis of the geological parameters of hardness, weathering, and joint spacing. The rock mass classification applied for excavation purposes in the project area is summarised in Fig. 4. The percentage of various rock classes encountered during the underground excavation was: SS- $1=24.93 \%$, SS- $2=10.97 \%$, SS-3 $=1.2 \%$, ST $-1=19.49 \%$, ST $-2=36.87 \%$, and ST $-3=6.53 \%$. The rock classes SS-1, SS-2, and SS-3 belong to the sandstone group while ST-1 and ST-2 to the siltstone group, and ST-3 to the claystone group. The latter is the weakest (whether it is fresh or weathered) rock mass of the project area with high cohesion and plasticity values (Table 1). Depending upon the rock class, standard support patterns were applied in order to stabilise the tunnel openings. At the same time, the deformation in the tunnel was monitored at regular intervals. The majority of specified supports adopted in the project site worked well except for the slaking siltstone (ST-2) and swelling clay (ST-3). 
Table 2 illustrates that ST-3 is the weakest rock class, which includes not only the soft claystone but also the highly weathered and well-jointed siltstone. On the other hand, SS-3 and ST-3 were weaker than SS-2 and ST-2. Similarly, SS-1 and ST-1 were stronger, but SS-1 was the strongest of all the classes and required the least support. The worst zones of the soft swelling clays of ST-3 category were encountered in the drainage tunnel and upper access tunnel to penstock.

\section{EFFECT OF JOINT PATTERNS IN TUNNEL STABILITY}

Table 3 relates the tunnel stability conditions with the orientation of discontinuities. It shows that the joints running parallel to the tunnel axis with the dip amount exceeding 45 degrees create the most unfavourable conditions. Similarly, dips of 20-45 degrees against heading are in unfavourable conditions. For most of unfavourable conditions, rock bolts were used to stabilise the jointed rock mass. In the Lam Ta Khong project, the major joint sets present in the sandstone were in very unfavourable to fair conditions. Similarly, in the siltstone, the major joints observed were in unfavourable to fair conditions. The strong support comprised shotcrete with steel fibre $(15 \mathrm{~cm}$ thick), wire mesh, and rock bolts. Sometimes, steel ribs were also applied in addition to these, depending upon the type of rock mass.

The sandstone in the project area is blocky, jointed, and fractured. The joints are usually filled up with gypsum and sometimes with clay, but frequently they are tight with smooth and planner surfaces. On the other hand, the joints with slickensides were frequently observed in siltstone. The slickenside surfaces were rather smooth and contributed to easy separation of the blocks upon contact with water resulting in block fall.

In addition to crosscutting joints, the contact boundary also created block fall during or soon after excavation. In the project area, the block fall occurred frequently along the contact between sandstone and siltstone as a result of the heavy weight of sandstone on weak siltstone.

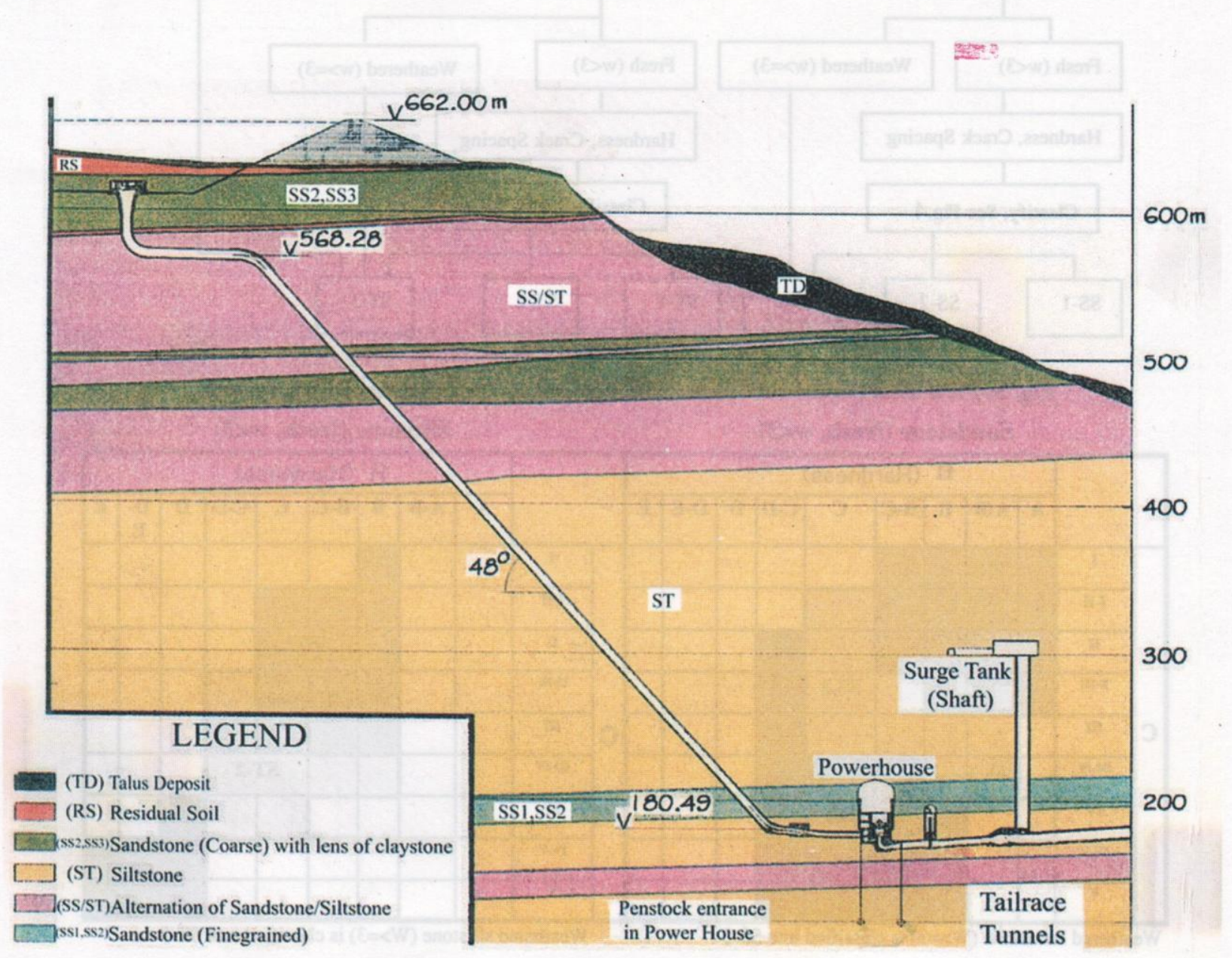

Fig. 2: Geological cross-section showing locations of principle project features 
Information on the discontinuities in the site is essential for understanding the geo-structural stability. The initial investigation during tender stage did not reveal enough details on the total sets of discontinuities present in the rock mass of the project area. Hence, this information was collected from the daily geological mapping. The orientation (dip/strike) of joints from engineering geological observations was used to plot in stereographic projections. The stereographic plots of discontinuities (Fig. 5) were carried out by applying a computer program DIPS, Version 3 (Diederichs and Hoek 1989). The plots for the tailrace tunnel number 1 (Fig. 5a) shows that, there are three major joint sets with the poles dipping 5-38 degrees due NNE, EES, and SSW, respectively. One rare joint set has the pole dipping due WWN with gentle dip. Frequent block falls occurred in effect of these joint sets. On the other hand, the pole plot for the drainage tunnel in the powerhouse (Fig. 5b) shows that the major joint sets exhibit varying dip angles ranging from

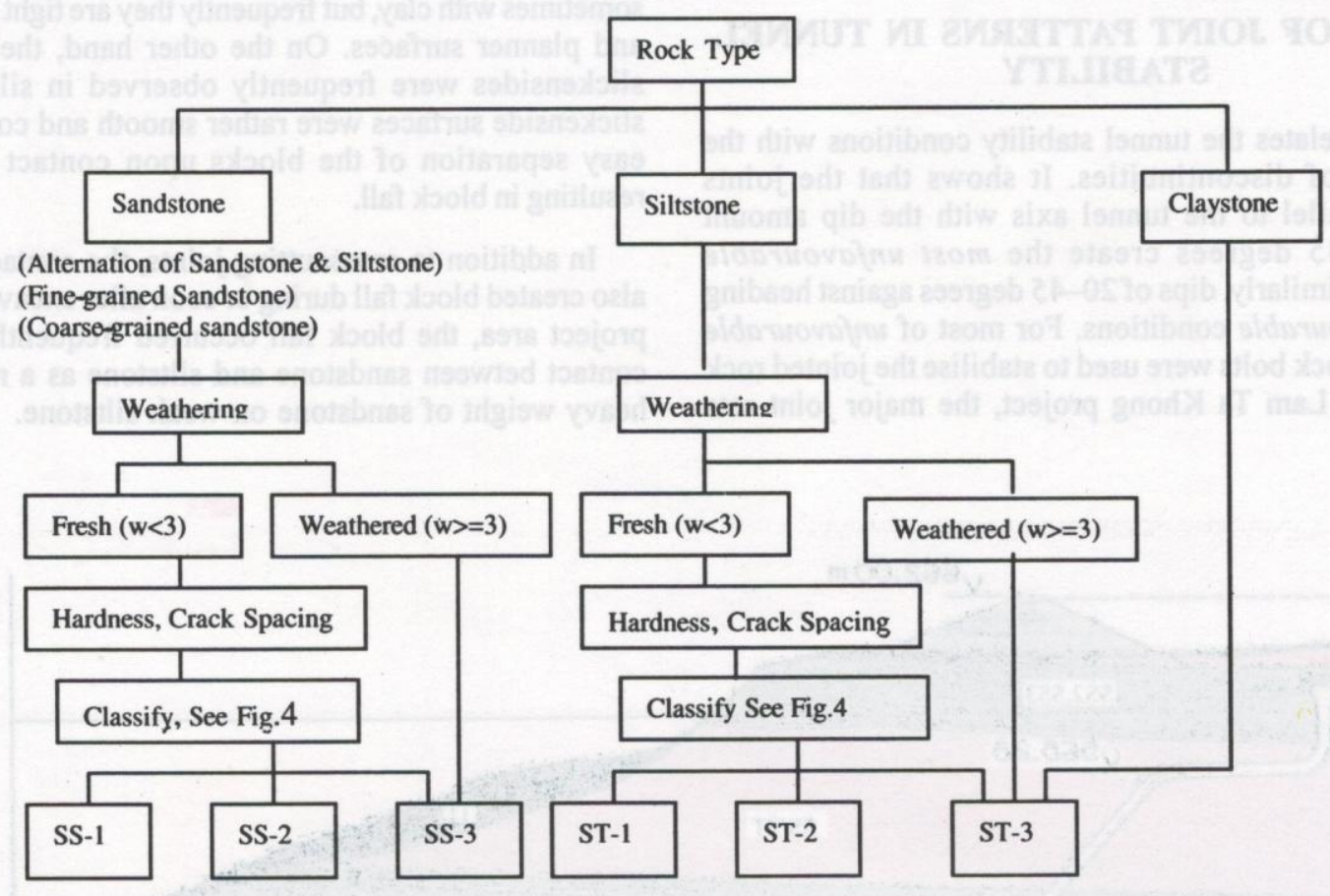

Fig. 3: Flow chart of the rock mass classification according to the EPDC system

Sandstone (fresh, w $<3$ )

Siltstone (fresh, $\mathbf{w}<\mathbf{3}$ )

\begin{tabular}{|c|c|c|c|c|c|c|c|c|c|c|c|c|c|c|c|c|c|c|c|c|c|}
\hline & \multicolumn{9}{|c|}{ H (Hardness) } & & & \multicolumn{9}{|c|}{ H (Hardness) } \\
\hline & & $\overline{\mathbf{A}}$ & A-B & B & B-C & $\mathbf{C}$ & C-D & D & D-E & $\mathbf{E}$ & & & $\bar{A}$ & $\overline{A-B}$ & $\overline{\mathbf{B}}$ & B-C & $\overline{\mathbf{C}}$ & C-D & $\bar{D}$ & $\begin{array}{l}\text { D- } \\
\text { E }\end{array}$ & $\overline{\mathbf{E}}$ \\
\hline & $\begin{array}{l}I \\
\end{array}$ & & & & & & & & & & & $\mathbf{I}$ & & & & & & & & & \\
\hline & I-II & & SS. & & & & & & & & & I-II & & & & & & & & & \\
\hline & II & & & & & & & & & & & II & & & & ST & & & & & \\
\hline & II-III & & & & & SS-2 & & & & & & II-III & & & & & & & & & \\
\hline C & III & & & & & & & & & & C & III & & & & & & & & & \\
\hline & III.VV & & & & & & & & & & & $\overline{\mathrm{mIIVV}}$ & & & & & & & & & \\
\hline & IV & & & & & W. & & & & & & IV & & & & & & & & & \\
\hline & rv.v & & 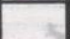 & & & & & & & & & IV.v & & & & & & & & X) & \\
\hline & $\bar{v}$ & & 3 & & & & & & & & & $\mathbf{v}$ & & & & & & & & & \\
\hline
\end{tabular}

Fig. 4: Rock mass classification based on EPDC system 
Table 1: Parameters for rock mass classification (EPDC 1992)

A: Weathering grade

\begin{tabular}{|c|l|}
\hline & \multicolumn{1}{|c|}{ Description } \\
\hline I & Very fresh. No weathering of mineral component. \\
\hline II & Fresh. Some minerals are weathered slightly. Usually, no brown crack. \\
\hline III & Fairly fresh. Some minerals are weathered. Cracks are stained and with weathered mineral. \\
\hline IV & Weathered. Fresh portions still remain partially. \\
\hline V & Strongly weathered. Most of minerals are weathered and altered to secondary minerals. \\
\hline
\end{tabular}

\section{B: Hardness}

\begin{tabular}{|c|l|c|}
\hline & \multicolumn{1}{|c|}{ Description } & $\begin{array}{c}\text { Compressive } \\
\text { strength Qu } \\
\text { QPa) }\end{array}$ \\
\hline A & Very hard. Broken into knife-edged pieces with repeated heavy hammer blows. & more than 70 \\
\hline B & Hard. Broken into fragments with one heavy hammer blow & 50 to 70 \\
\hline C & Moderately hard. Broken into small fragments with one sharp hammer blow. & 30 to 50 \\
\hline D & $\begin{array}{l}\text { Moderately Soft. Broken in the hands, but does not crumble readily. Rock is } \\
\text { considerably deformed when struck by. }\end{array}$ & less than 30 \\
\hline E & Soft. Material can be dug out and crumbled with finger & \\
\hline
\end{tabular}

C: Crack spacing

\begin{tabular}{|c|c|c|c|c|c|c|}
\hline & $\mathbf{0}$ & I & II & III & IV & V \\
\hline Description & Over $200 \mathrm{~cm}$ & 100 to $200 \mathrm{~cm}$ & 40 to $100 \mathrm{~cm}$ & 20 to $40 \mathrm{~cm}$ & 5 to $20 \mathrm{~cm}$ & Under $5 \mathrm{~cm}$ \\
\hline
\end{tabular}

Table 2: Representative lithology of each rock mass class (EPDC 1992)

\begin{tabular}{|l|c|l|}
\hline Rock type & Rock mass class & \multicolumn{1}{c|}{ Lithology } \\
\hline \multirow{4}{*}{ Sandstone } & SS-1 & Fresh, massive to slightly jointed \\
\cline { 2 - 3 } & SS-2 & Fresh, moderately jointed \\
\cline { 2 - 3 } & SS-3 & Both fresh and weathered, highly jointed \\
\hline \multirow{3}{*}{ Siltstone } & ST-1 & Fresh, massive to slightly jointed \\
\cline { 2 - 3 } & ST-2 & Fresh, moderately jointed \\
\cline { 2 - 3 } & ST-3 & Both fresh and weathered, highly jointed \\
\hline Claystone & ST-3 & Both fresh and weathered \\
\hline
\end{tabular}

Table 3: Effect of discontinuity orientation in tunnelling

\begin{tabular}{|c|c|c|c|c|c|c|}
\hline \multicolumn{4}{|c|}{ Strike perpendicular to tunnel axis } & \multirow{2}{*}{\multicolumn{2}{|c|}{$\begin{array}{l}\text { Strike parallel to tunnel } \\
\text { axis }\end{array}$}} & \multirow[b]{2}{*}{ Irrespective of strike } \\
\hline \multicolumn{2}{|c|}{ Drive with dip } & \multicolumn{2}{|c|}{ Drive against dip } & & & \\
\hline Dip & Dip & Dip & Dip & Dip & Dip & Dip \\
\hline $45-90^{\circ}$ & $20-45^{\circ}$ & $45-90^{\circ}$ & $20-45^{\circ}$ & $20-45^{\circ}$ & $45-90^{\circ}$ & $0-20^{\circ}$ \\
\hline $\begin{array}{c}\text { Very } \\
\text { favourable }\end{array}$ & Favourable & Fair & Unfavourable & Fair & $\begin{array}{c}\text { Very } \\
\text { unfavourable }\end{array}$ & Fair \\
\hline
\end{tabular}

Modified after Wickham et al. (1974) 
nesh P. Dhakal et al.

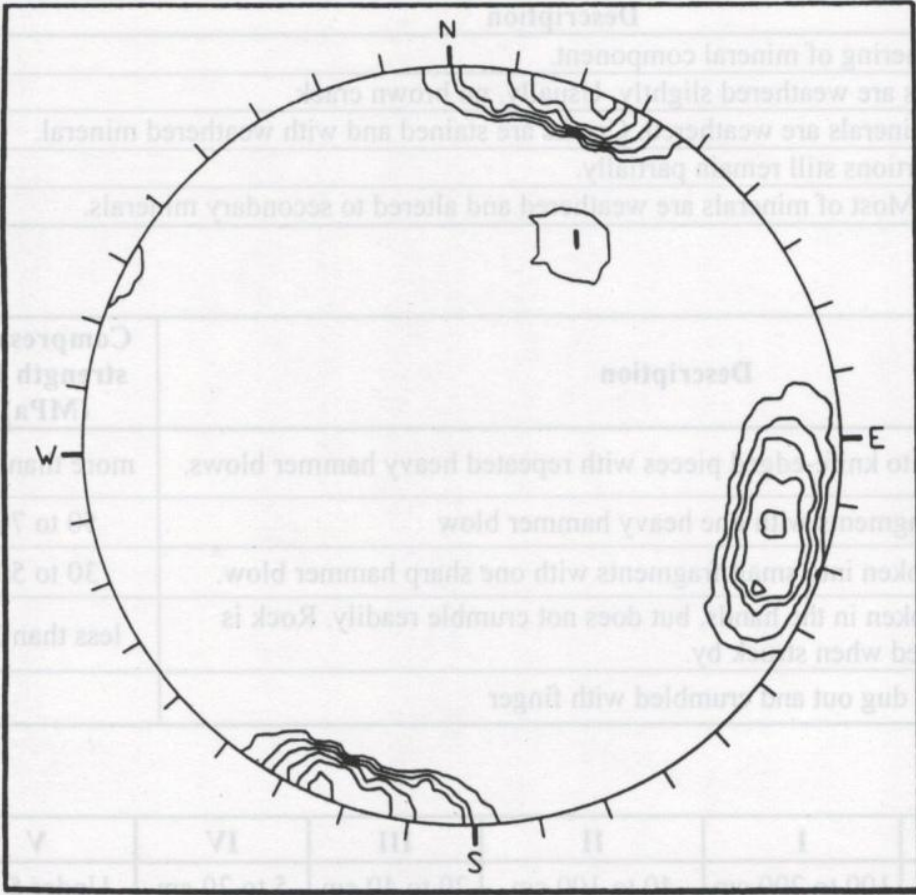

\section{Equal Angle \\ Lower Hemisphere}

Contour Plot

Schmidt Pole Concentrations,

$\%$ of total per $1.0 \%$ area

Min. Contour $=3.5$

Contour Interval $=3.5$

Max. . Concentration $=22.3$

112 Poles plotted

112 Data entries

a. Tailrace No. 1

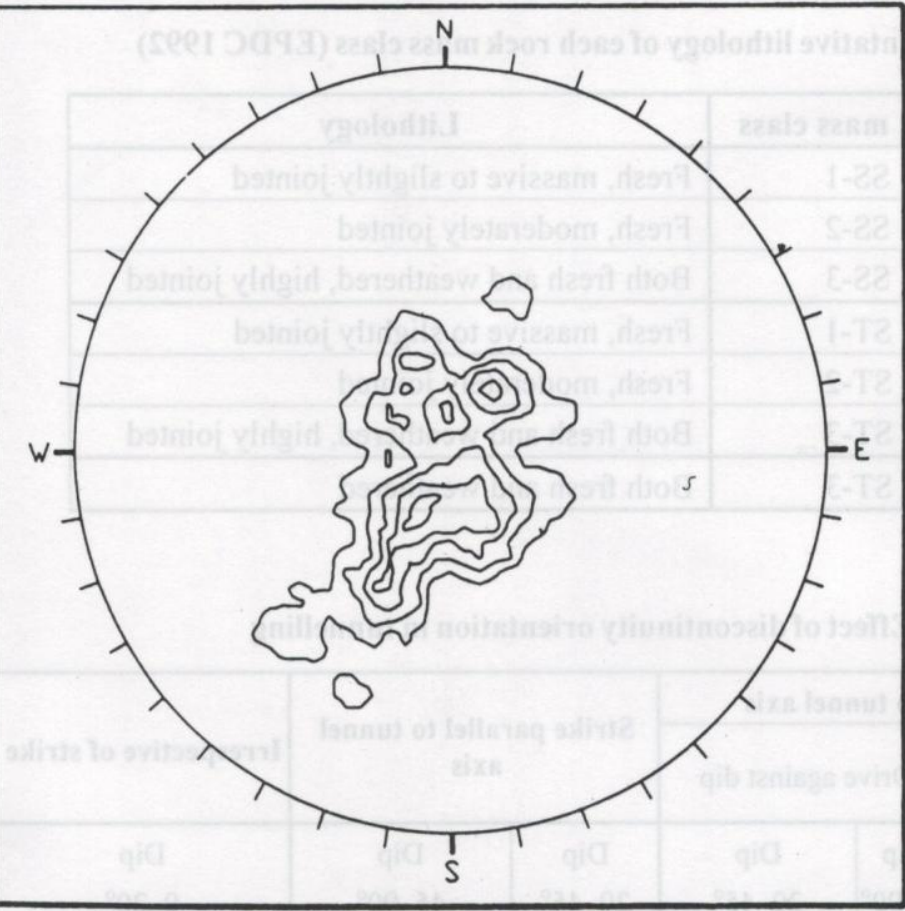

\section{Equal Angle \\ Lower Hemisphere}

Contour Plot

Schmidt Pole Concentrations,

$\%$ of total per $1.0 \%$ area

Min. Contour $\quad=1.5$

Contour Interval $=1.5$

Max. . Concentration $=8.87$

282 Poles plotted

283 Data entries

b. DrainageTunnel (Powerhouse)

Fig. 5: Stereographic projection of the poles of measured joints 
15 to 90 degree. The vertical joints in the tunnel created frequent block falls from the crown and sidewalls.

\section{EXTENSOMETER MEASUREMENTS IN THE POWERHOUSE CAVERN}

The movements due to excavation in the powerhouse were monitored by nine multiple borehole extensometers each with four measuring heads (points). Three extensometers each in a same vertical plane from Top Gallery, three from Draft Gate Hall, and three from the Drainage Gallery were installed and monitored. The extensometers from the Draft Gate Hall and Drainage Gallery were installed almost horizontally (i.e., less than 10 degrees) extending towards the powerhouse. The Geodata rod-type extensometers used in this project consisted of a measuring head with adjustable dial gauge stop, a measuring rod with protective tube and an anchor part. The dial gauge stop was designed for exact dial gauge measurements. Later on, for remote reading of installations with automated monitoring, the rod extensometers were equipped with a displacement transducer. Due to safety reasons, displacement measurements were always carried out at two shifts after the excavation.

The measurement results from the Top Gallery (the tunnel above powerhouse cavern) are given in Fig. 6. It shows a gradual nominal movement. At the beginning, the difference in values shows some small irregular movements, which later on become gradual. The difference observed from the longest one $(C E 1-1=14.8 \mathrm{~m})$ was $0.098 \mathrm{~mm} /$ day, from the second one $(\mathrm{CE} 1-2=12.3 \mathrm{~m}$ ) was $0.0394 \mathrm{~mm} /$ day, and from the third one (CE1-3 $=9.3 \mathrm{~m}$ ) was $0.0367 \mathrm{~mm} /$ day, and from the shortest one (CE1-4=5.3 m) was $0.0245 \mathrm{~mm} /$ day. Thus, the average difference value observed was $0.0498 \mathrm{~mm} /$ day. The extensometer measurements from the Draft Gate Hall and Drainage Gallery also showed similar trends.

Hence, the displacements were considered to be within the creep phase where the instantaneous elastic deformation was absent. All the extensometer measurements with nominal differences in displacement (less than $0.05 \mathrm{~mm} /$ day) indicated that the powerhouse was safe (Bieniawski 1984).

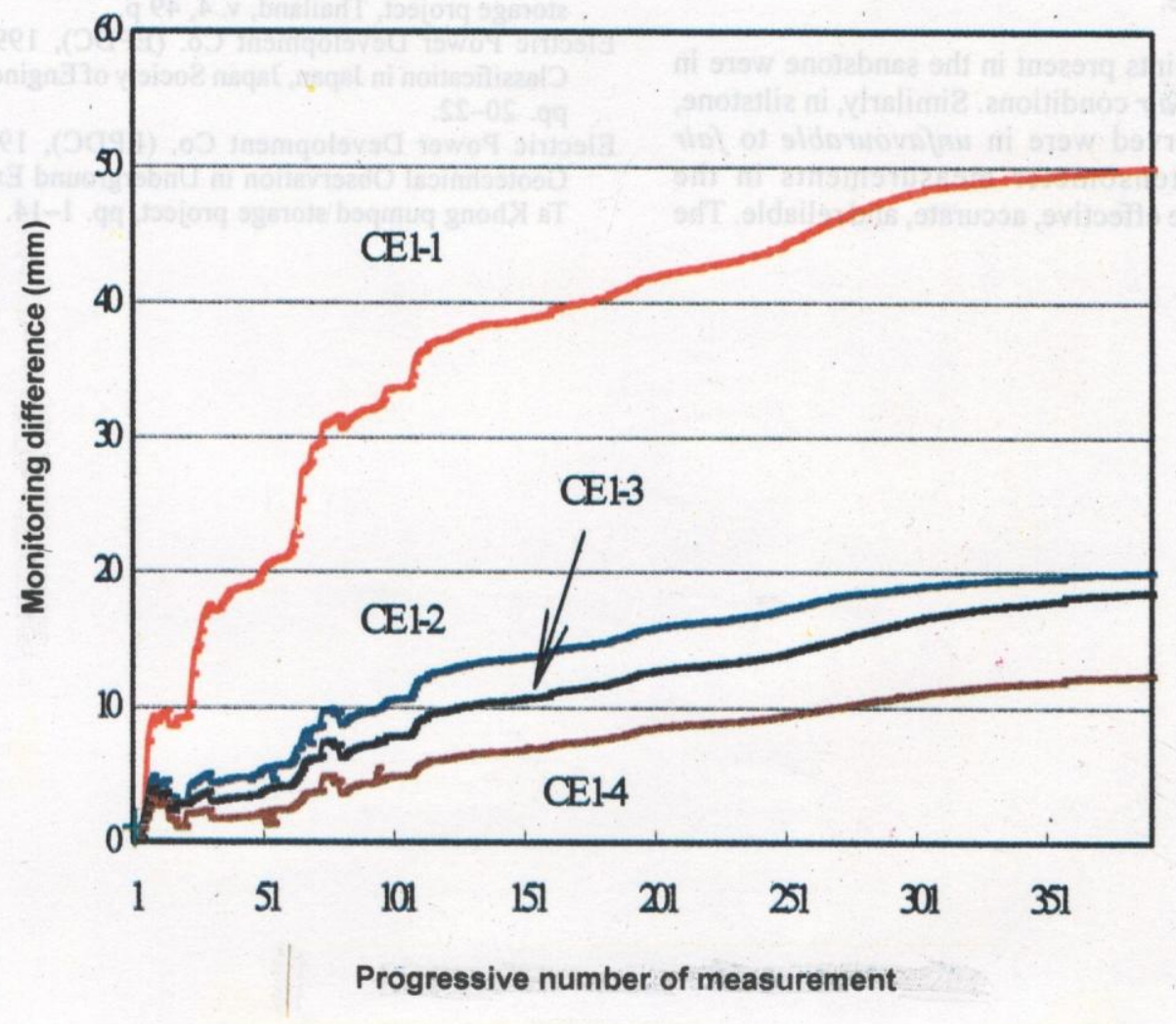

Fig. 6: Extensometer monitoring from Top Gallery (CE-1). CE-1 is an extensometer with four measuring heads (CE 1-1, CE 1-2, CE 1-3 and CE 1-4) installed from Top Gallery vertically downwards. 


\section{CONCLUSIONS}

The Jurassic sedimentary rocks of the Korat Group are distributed in the project area, which are divided into the Phu Kradung and Phra Wiham Formations in an ascending order. Lithologically, the bedrock of the project area is divided into three rock types, which are the sandstone, siltstone, and claystone groups. The sandstone group consists of coarse-grained sandstone, fine-grained sandstone, and an interbedding of sandstone and siltstone.

The EPDC system of rock mass classification was very useful for the rocks of the Lam Ta Khong project area. According to it, the rock masses were categorised into SS-1, SS-2, and SS-3 classes for the sandstone group, and ST-1, ST-2, and ST-3 for the siltstone group. The claystone group belonged to the ST-3 class. Weathering, hardness, and joint spacing were the main input parameters used for classifying the rocks into these categories. The percentage of various rock classes encountered during underground excavation was: SS- $1=24.93 \%$, SS- $2=10.97 \%$, SS- $3=1.2 \%$, ST $-1=19.49 \%$, ST- $2=36.87 \%$, and ST $-3=6.53 \%$. It is observed that the standard support pattern adopted for the project worked satisfactorily despite the weak, soft, and well-jointed rock conditions. The adopted method of excavation in the project area was quite suitable.

The majority of joints present in the sandstone were in very unfavourable to fair conditions. Similarly, in siltstone, the main joints observed were in unfavourable to fair conditions. The extensometer measurements in the powerhouse were quite effective, accurate, and reliable. The average displacement of $0.0498 \mathrm{~mm} /$ day indicated safe conditions in the powerhouse.

\section{ACKNOWLEDGEMENTS}

The authors are highly indebted to Professor K. Kaneko of Hokkaido University for his constant encouragement and suggestions. Thanks are also due to Enrique Fernandez Gonzalez, Underground Superintendent of the Lam Ta Khong Pumped Storage Project who helped by providing necessary information for this report. The authors are also grateful to Mr. Seiji Hongo who provided necessary guidance during the preparation of this paper.

\section{REFERENCES}

Bieniawski, Z. T., 1984, Rock Mechanics Design in Mining and Tunnelling. Rainbow-Bridge Book Co. Ltd., pp. 148-149.

Bieniawski, Z. T., 1989, Engineering Rock Mass Classifications. Wiley, New York, 251 p.

Diederichs, M. S. and Hoek, E., 1989, DIPS Advanced version 3. Rock Engineering Group, Department of Civil Engineering, University of Toronto, Canada.

Electricity Generating Authority of Thailand (EGAT), 1995, Bidding Documents, Civil works of Lam Ta Khong pumped storage project, Thailand, v. 4, $49 \mathrm{p}$.

Electric Power Development Co. (EPDC), 1992, Rock mass Classification in Japan, Japan Society of Engineering Geology, pp. 20-22.

Electric Power Development Co. (EPDC), 1996, Guide for Geotechnical Observation in Underground Excavation, Lam Ta Khong pumped storage project, pp. 1-14. 